Article

\title{
G-Protein Coupled Receptor Protein Synthesis on a Lipid Bilayer Using a Reconstituted Cell-Free Protein Synthesis System
}

\author{
Belay Gessesse $^{1,2}$, Takashi Nagaike ${ }^{1}$, Koji Nagata ${ }^{3}$, Yoshihiro Shimizu ${ }^{2}$ and Takuya Ueda ${ }^{1, *}$ \\ 1 Department of Computational Biology and Medical Sciences, Graduate School of Frontier Sciences, \\ The University of Tokyo, Bldg. FSB-401, 5-1-5 Kashiwanoha, Kashiwa, Chiba 277-8562, Japan; \\ belaygessesse@gmail.com (B.G.); nagaike@edu.k.u-tokyo.ac.jp (T.N.) \\ 2 Laboratory for Cell-Free Protein Synthesis, RIKEN Center for Biosystems Dynamics Research (BDR), \\ 6-2-3, Furuedai, Suita, Osaka 565-0874, Japan; yshimizu@riken.jp \\ 3 Department of Applied Biological Chemistry, Graduate School of Agricultural and Life Sciences, \\ The University of Tokyo, 1-1-1 Yayoi, Bunkyo-ku, Tokyo 113-8657, Japan; aknagata@mail.ecc.u-tokyo.ac.jp \\ * Correspondence: ueda@edu.k.u-tokyo.ac.jp
}

Received: 31 August 2018; Accepted: 30 October 2018; Published: 2 November 2018

\begin{abstract}
Membrane proteins are important drug targets which play a pivotal role in various cellular activities. However, unlike cytosolic proteins, most of them are difficult-to-express proteins. In this study, to synthesize and produce sufficient quantities of membrane proteins for functional and structural analysis, we used a bottom-up approach in a reconstituted cell-free synthesis system, the PURE system, supplemented with artificial lipid mimetics or micelles. Membrane proteins were synthesized by the cell-free system and integrated into lipid bilayers co-translationally. Membrane proteins such as the G-protein coupled receptors were expressed in the PURE system and a productivity ranging from 0.04 to $0.1 \mathrm{mg}$ per $\mathrm{mL}$ of reaction was achieved with a correct secondary structure as predicted by circular dichroism spectrum. In addition, a ligand binding constant of $27.8 \mathrm{nM}$ in lipid nanodisc and $39.4 \mathrm{nM}$ in micelle was obtained by surface plasmon resonance and the membrane protein localization was confirmed by confocal microscopy in giant unilamellar vesicles. We found that our method is a promising approach to study the different classes of membrane proteins in their native-like artificial lipid bilayer environment for functional and structural studies.
\end{abstract}

Keywords: cell-free protein synthesis; artificial cell; lipid bilayer; membrane protein; G-protein coupled receptor; lipid nanodisc

\section{Introduction}

The advent of artificial cells has enabled us to study active membrane proteins that play a substantial role in various cellular activities and physiological functions under a defined condition [1,2]. Membrane proteins are expressed and localized to the biological membrane to modulate the functions of the membrane by regulating the bidirectional flux of molecules and cell-to-cell communications. It is estimated that about $30-50 \%$ of all pharmaceutical drugs target membrane proteins such as G-protein coupled receptors (GPCRs), ion channels, membrane transporters and enzymes [3-6].

The synthesis of active membrane proteins using artificial lipid bilayers has a significant advantage in examining the complex biochemical reactions and to screen for drug candidates. Artificial cells have been manipulated to study the functions of membrane proteins such as $\alpha$-hemolysin [7,8], a potassium channel, KcsA [9] and olfactory receptor complexes [10]. The use of artificial cells can also be extended to other classes of membrane proteins such as GPCRs which can respond to extracellular signals in the environment. Therefore, the synthesis and integration of active GPCRs into artificial lipid bilayer 
mimetics such as nanodiscs and giant unilamellar vesicles (GUVs) have a substantial role to screen ligands and to develop biosensors for medical applications [11].

Currently, cell-free protein synthesis systems have become an emerging potential bottom-up approach to study membrane proteins for functional and structural analysis. The Protein Synthesis Using Recombinant Elements system (PURE system) is an E. coli based cell-free system which contains purified components of transcriptional and translational factors at a defined concentration unlike the total E. coli extract based cell-free system [12]. This enables us to control and modify the system more easily as per our objectives. Moreover, the PURE system is devoid of nucleases and proteases and offers improved controllability. To date, various functional membrane proteins were synthesized by the cell-free systems supplemented with detergents, chaperones, micelles, liposomes and nanodiscs. These include C-C Chemokine receptor type 5 (CCR5) [13], claudin-4 [14], secYEG [15] and human endothelin B receptor (ETB) [16].

Incorporation of lipid nanodiscs (NDs) into the cell-free system during membrane protein expression has a greater advantage over vesicle-based mimetics such as GUVs. Nanodiscs are generally soluble, stable, monodisperse and more importantly, both the $\mathrm{N}$ - and C-terminus are accessible for ligand binding assays $[17,18]$. Recently, the nanodisc technology has been used for the reconstitution of various membrane proteins such as a G-protein coupled receptor, CCR5 [19], an ion channel TRPV1 [20] and a transporter, MsbA [21]. In addition to the direct reconstitution of purified membrane proteins into nanodiscs, co-translational integration of membrane proteins by a cell-free system was nonetheless used for adrenergic receptor 1 (31AR) [22] and endothelial receptor (ETB) [16,23]. From a structural point of view, nanodiscs in combination with cell-free systems will offer a greater advantage in determining the structure of membrane proteins in their native-like lipid bilayer by cryo-electron microscopy (cryo-EM) [21,24].

In this study, we used a PURE system based co-translational integration of GPCRs into artificial lipid bilayers and micelles for functional and structural analysis. To gain an insight into the functions of GPCRs, we chose the chemokine GPCRs, $\mathrm{CX}_{3} \mathrm{CR} 1$ and $\mathrm{CCR} 5$ as model proteins. We systematically optimized the expression and analyzed the secondary structure, membrane localization, activity and homogeneity of the synthesized chemokine GPCRs by using nanodiscs, GUVs and micelles (Figure 1A-C).

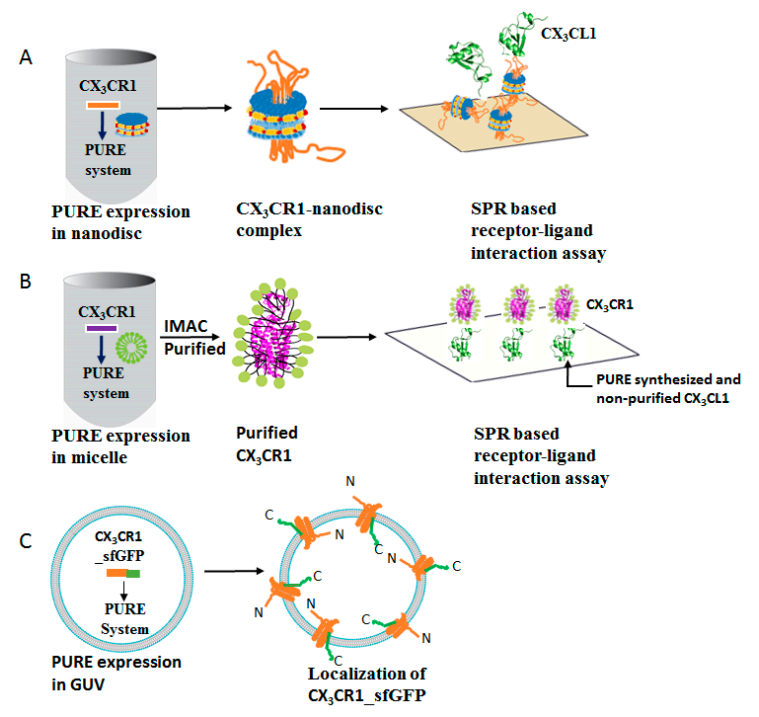

Figure 1. Schematic representation of the cell-free expression of GPCRs. $\mathrm{CX}_{3} \mathrm{CR} 1$ was synthesized by the PURE system supplemented with lipid nanodiscs (A), micelle (B), or CX ${ }_{3}$ CR1-sfGFP synthesized inside GUV (C). The GPCR-nanodisc complex was immobilized on a sensor chip without prior purification for Surface Plasmon Resonance (SPR) based ligand binding assay. Similarly, PURE expressed $\mathrm{CX}_{3} \mathrm{CR} 1$ in micelle was purified and allowed to interact with pre-immobilized PURE expressed and non-purified $\mathrm{CX}_{3} \mathrm{CL} 1$ to determine the binding affinity by SPR. The localization of $\mathrm{CX}_{3} \mathrm{CR} 1$-sfGFP was probed by confocal microscopy. 


\section{Materials and Methods}

\subsection{Materials}

Synthetic lipids such as 1-palmitoyl-2-oleoyl-glycero-3-phosphocholine (POPC), 1-palmitoyl2-oleoyl-sn-glycero-3-phospho-L-serine (sodium salt) (POPS), 1,2-distearoyl-sn-glycero-3-phosphoetha nolamine- $N$-[methoxy(polyethylene glycol)-2000] (ammonium salt) (PEG2000-DOPE) were purchased from Avanti Polar Lipids, Inc. (Alabaster, AL, USA); Cholesterol from Nacalai tesque, Inc. (Kyoto, Japan); SM2 bio-beads from Bio-rad (Hercules, CA, USA); Penta-His antibody from Qiagen (Hilden, Germany); StrepMAB-Immo from IBA Lifesciences (Goettingen, Germany); CM5 and amine coupling reagents from GE Healthcare (Chicago, IL, USA).

\subsection{Preparation of DNA Constructs}

The cDNAs of human GPCRs, $\mathrm{CX}_{3} \mathrm{CR} 1$ and CCR5, were a kind gift from Dr. Yutaka Suzuki (University of Tokyo). The sequence of $\mathrm{CX}_{3} \mathrm{CR} 1$ was optimized for $E$. coli expression by Genscript whereas the sequence of human CCR5 was used without optimization. Plasmids and linear PCR products of both $\mathrm{CX}_{3} \mathrm{CR} 1$ and $\mathrm{CCR} 5$ were constructed and used as a DNA template for protein expression. The PCR fragment of both $\mathrm{CX}_{3} \mathrm{CR} 1$ and CCR5 were generated by two-step overlap PCR using a forward primer containing a T7 promoter and Shine Dalgarno sequence and a reverse primer with or without a His-tag. To enhance the stability of CCR5, a rubredoxin was inserted between amino acid residues Arg223 and Glu227 [25] to produce a stabilized CCR5 variant, CCR5-Rb, in which the template DNA preparation was the same as $C X_{3} C R 1$ and CCR5. The expression plasmids of $C X_{3} C R 1$, CCR5 and CCR5-Rb were constructed by infusion cloning of the DNA containing 6xhis tag and Tev recognition site preceded with a linker (DYDIPTT) at the N-terminus to $\mathrm{pET28a}$ vector digested with $\mathrm{NcoI}$ and $\mathrm{XhoI}$ restriction enzymes. For localization experiment, $\mathrm{CX}_{3} \mathrm{CR}$-sfGFP fusion construct was made by fusing sfGFP to the C-terminus of $\mathrm{CX}_{3} \mathrm{CR} 1 \mathrm{DNA}$ by overlap PCR and cloned to pET28a vector digested with EcoRI and $\mathrm{XhoI}$ restriction enzymes through infusion cloning. According to a previously reported method [26], the ligand fractalkine ( $\left.\mathrm{CX}_{3} \mathrm{CL1}\right)$ containing strep-tag II at the $\mathrm{N}$-terminus was amplified from pUREstrept2 plasmid for immobilization and binding assay.

\subsection{Membrane Scaffold Protein (MSP) Expression}

The expression and purification of MSP were carried out according to the established protocols with slight modifications [27]. Briefly, the expression host BL21 (DE3) containing either MSP1D1 (addgene\#20061) or MSP1E3D1 (addgene\#20066) plasmids were expressed in 3 L LB culture medium containing $50 \mu \mathrm{g} / \mathrm{mL}$ kanamycin at $37^{\circ} \mathrm{C}$ with shaking and at $\mathrm{OD}_{600} 0.8-1$, the culture was induced with $1 \mathrm{mM}$ IPTG. The culture was further incubated for $1 \mathrm{~h}$ at $37^{\circ} \mathrm{C}$ and for $3 \mathrm{~h}$ at $28^{\circ} \mathrm{C}$ to prevent aggregation. The cell pellet was then collected at $8000 \times g$ for $15 \mathrm{~min}$ at $4{ }^{\circ} \mathrm{C}$, washed with MSP buffer containing EDTA, flash frozen in liquid $\mathrm{N}_{2}$ and stored at $-80^{\circ} \mathrm{C}$. For purification, the MSP was thawed at room temperature for $30 \mathrm{~min}$ and suspended with lysis buffer $(40 \mathrm{mM}$ Tris $/ \mathrm{HCl}, \mathrm{pH} 8.0,300 \mathrm{mM}$ $\mathrm{NaCl})$ containing $1 \%$ Triton $\mathrm{X}-100$, protease inhibitor cocktail and DNase ( $0.5 \mathrm{mg}$ for 5 gm cell pellet). The supernatant was then centrifuged at $30,000 \times g$ for $30 \mathrm{~min}$ at $4{ }^{\circ} \mathrm{C}$ to remove the cell debris and purified by IMAC affinity chromatography using Ni-NTA column pre-equilibrated with lysis buffer containing $1 \%$ Triton X-100. Subsequently, the column was washed with buffers $\mathrm{A}_{\mathrm{msp}}$ (Lysis Buffer containing 1\% Triton X-100), $B_{\mathrm{msp}}$ (Lysis Buffer containing $50 \mathrm{mM}$ Na Cholate, $20 \mathrm{mM}$ Imidazole), $\mathrm{C}_{\mathrm{msp}}$ (Lysis Buffer containing $50 \mathrm{mM}$ Imidazole). The MSP protein was later eluted with buffer $\mathrm{D}_{\mathrm{msp}}$ (Lysis Buffer containing $400 \mathrm{mM}$ Imidazole), analyzed by 15\% SDS-PAGE and buffer exchanged with $20 \mathrm{mM}$ Tris/ $\mathrm{HCl}, \mathrm{pH}$ 8.0, $100 \mathrm{mM} \mathrm{NaCl}$ and $0.5 \mathrm{mM}$ EDTA in a PD-10 column. Finally, the fraction containing pure protein was collected, concentrated, aliquoted and flash frozen in liquid nitrogen at $-80{ }^{\circ} \mathrm{C}$ until further use. The protein concentration was determined by absorbance at $280 \mathrm{~nm}$ with an extinction coefficient of $\varepsilon_{280}=21,000 \mathrm{M}^{-1} \mathrm{~cm}^{-1}$ and $\varepsilon_{280}=29,400 \mathrm{M}^{-1} \mathrm{~cm}^{-1}$ for MSP1D1 and MSP1E3D1 respectively. 


\subsection{Nanodisc (ND) Preparation}

Nanodiscs were prepared according to previous reports with slight modification [28-30]. In brief, synthetic lipids POPC, POPS and Cholesterol were dissolved in chloroform and mixed at a ratio of $72 \%$, $20 \%$ and $8 \%$ respectively. The mixture was then flushed with $\mathrm{N}_{2}$ gas and dried overnight in a vacuum. The dried lipid film was solubilized by a nanodisc buffer $(20 \mathrm{mM}$ Tris/HCl, pH 7.4 and $100 \mathrm{mM}$ $\mathrm{NaCl}$ ) containing $100 \mathrm{mM} \mathrm{Na}$ cholate. To achieve complete solubilization, the mixture was vortexed followed by heating at $60^{\circ} \mathrm{C}$ in a water bath until the lipid film completely dissolved. Finally, detergent solubilized lipid was mixed either with MSP1D1 or MSP1E3D1 at the respective molar ratio of 1:60 and 1:85 respectively and incubated at $4{ }^{\circ} \mathrm{C}$. After $1 \mathrm{~h}$ of incubation, an adsorbent, SM2 bio-beads from Bio-rad (Hercules, CA, USA), was added to remove the detergent and to facilitate nanodisc formation. The reaction mixture was further incubated from $6 \mathrm{~h}$ to overnight and the Biobeads were removed by centrifugation at $130,000 \times g$ for 2 min using a $0.2 \mu \mathrm{m}$ NANOSEP device from PALL Life Sciences (Port Washington, NY, USA). To remove the aggregates, the nanodisc was further centrifuged at $18,000 \times g$ for $5 \mathrm{~min}$ before loading to Superdex-200 10/300 from GE Healthcare (Chicago, IL, USA) for further purification.

\subsection{PURE Synthesis of Membrane Proteins}

A PURE system (PUREfrex 2) prepared according to published protocols [31] and purchased from Genefrontiers (Kashiwa, Japan) were used for membrane protein synthesis. To facilitate correct disulfide bond formation, we used a modified PURE system in which the DTT was replaced by glutathione reduced (GSH). A GPCR was synthesized from $5 \mathrm{nM}$ DNA template by the PURE system in the presence or absence of nanodiscs in a $20 \mu \mathrm{L}$ reaction volume and incubated at $37^{\circ} \mathrm{C}$ for $6 \mathrm{~h}$. After the reaction, the synthesized membrane protein was aliquoted into $5 \mu \mathrm{L}$ as a total fraction. The remaining $15 \mu \mathrm{L}$ was centrifuged at $20,400 \times g$ for $10 \mathrm{~min}$ at $4{ }^{\circ} \mathrm{C}$ and the supernatant was collected. A sample loading dye was added at a 1:1 $(v / v)$ ratio to the total and supernatant fraction and run on $15 \%$ SDS-PAGE. For radiolabeling based quantification, ${ }^{35} \mathrm{~S}$-methionine incorporation by the PURE system into the membrane protein was measured by BAS-5000 from Fujifilm (Tokyo, Japan) and the band intensity was quantified by Multi Gauge software (Tokyo, Japan).

\subsection{Purification of Membrane Protein-Nanodisc Complex}

After PURE synthesis, the reaction mixture was centrifuged at $18,000 \times g$ for $3 \mathrm{~min}$ at $4{ }^{\circ} \mathrm{C}$ prior to purification. The supernatant was mixed with Ni-NTA equilibrated with buffer $\mathrm{A}_{\text {cplx }}(20 \mathrm{mM}$ Tris $/ \mathrm{HCl}$, $\mathrm{pH} 8.0,150 \mathrm{mM} \mathrm{NaCl}$ ) and incubated at $4{ }^{\circ} \mathrm{C}$ for $1 \mathrm{~h}$ with shaking. The column was washed with wash buffer $\mathrm{B}_{\text {cplx }}$ (buffer A containing $30 \mathrm{mM}$ Imidazole) and the nanodisc-membrane protein complex was eluted with buffer $\mathrm{C}_{\text {cplx }}$ (buffer A containing $300 \mathrm{mM}$ Imidazole. The elution fraction was run on SDS-PAGE to monitor the purity of the purification and buffer exchanged by dialysis with the elution buffer without imidazole, concentrated and quantified by $\mathrm{A}_{280}$ absorbance. For transmission electron microscopy, the elution fraction after IMAC purification was diluted 1:1 $(v / v)$ in nanodisc buffer and further purified by size exclusion chromatography in a Superdex-200 10/300 column (GE Healthcare) using a nanodisc buffer.

\subsection{Circular Dichroism (CD) Spectroscopy}

Far-UV CD measurements were performed on J720 spectropolarimeter from Jasco (Tokyo, Japan) using a Teflon sealed $1 \mathrm{~mm}$ path length quartz glass cuvette from Hellma Analytics (Mullheim, Germany). A wavelength increment of $1 \mathrm{~nm}$, a response time of $4 \mathrm{~s}$, a scan speed of $20 \mathrm{~nm} / \mathrm{min}$ parameters and a concentration of $0.15 \mathrm{mg} / \mathrm{mL}$ of $\mathrm{CX}_{3} \mathrm{CR} 1$ and $0.11 \mathrm{mg} / \mathrm{mL}$ of CCR5-Rb were used during measurement. All the resulting spectra were buffer corrected. 


\subsection{Preparation of Membrane Proteins for CD Spectroscopy by Micelle Method}

Mixed Micelles were prepared as described in Shinoda et al. [14] from $25 \mathrm{mg} / \mathrm{mL}$ brain polar lipid and $75 \mathrm{mg} / \mathrm{mL}$ of digitonin detergent and tip sonicated until the mixture becomes transparent. The micelle at 0.15 volume of reaction was added to a PURE based cell-free system and the reaction mixture was incubated for $4 \mathrm{~h}$ at $37^{\circ} \mathrm{C}$. After protein synthesis, the mixture was centrifuged at $100,000 \times \mathrm{g}$ for $30 \mathrm{~min}$ at $4{ }^{\circ} \mathrm{C}$ and the supernatant was applied to Ni-NTA pre-equilibrated with buffer A (20 mM Tris/ $\mathrm{HCl}, \mathrm{pH} 8,150 \mathrm{mM} \mathrm{NaCl}, 0.05 \%$ DDM and $0.002 \% \mathrm{CHS}$ ) and incubated at $4{ }^{\circ} \mathrm{C}$ for $1 \mathrm{~h}$ with gentle shaking. IMAC purification was carried out by washing the column in buffer $\mathrm{B}$ (buffer A containing $20 \mathrm{mM}$ Imidazole) and the recombinant protein was eluted with buffer $\mathrm{C}$ (buffer A supplemented with $300 \mathrm{mM}$ Imidazole). The eluate was then concentrated and buffer exchanged with buffer A by repeated dilute and concentrate method in a $10 \mathrm{kDa}$ MWCO from Merck Millipore (Tullagreen, Ireland). The concentration of the protein was finally quantified by $\mathrm{A}_{280}$ absorbance in nanodrop 1000 from Thermo Fisher Scientific (Waltham, MA, USA) and used for CD measurement.

\subsection{Electron Microscopy of $\mathrm{CX}_{3}$ CR1-Nanodisc Complexes}

IMAC purified $\mathrm{CX}_{3} \mathrm{CR}$-nanodisc complexes were further purified by size exclusion chromatography and concentrated to $0.25 \mathrm{mg} / \mathrm{mL}$ using a $30 \mathrm{kDa}$ molecular weight cutoff (Merck Millipore). About $2 \mu \mathrm{L}$ of the $\mathrm{CX}_{3} \mathrm{CR} 1$-nanodisc complex at $100 \mathrm{nM}$ was deposited on a glow-discharged copper grid, incubated for $1 \mathrm{~min}$ and blotted away using a filter paper. Immediately after blotting, the grid was stained with $5 \mu \mathrm{L}$ of $2 \%(w / v)$ uranyl acetate and blotted away after $30 \mathrm{~s}$ incubation at room temperature. The spotted sample was then dried at room temperature or using a lamp for quick drying and electron micrographs were recorded on H-7000 electron microscopy from Hitachi (Tokyo, Japan) operated at an acceleration voltage of $100 \mathrm{kV}$ and at 30,000 $\times$ magnification.

\subsection{Giant Unilamellar Vesicle (GUV) Preparation}

Giant unilamellar vesicle preparation was carried out according to established protocols with slight modification [8]. Briefly, POPC lipid or a mixture of POPC and PEG2000PE (9.75: 0.25 molar ratio) was mixed, at the concentration of $10 \mathrm{mM}$, with $500 \mu \mathrm{L}$ liquid paraffin. The mixture was vortexed vigorously, flushed with $\mathrm{N}_{2}$ gas and heated at $80^{\circ} \mathrm{C}$ for $20 \mathrm{~min}$. The heated lipid-paraffin mixture was vortexed until it gets cooled. The lipid-paraffin mix was flushed with $\mathrm{N}_{2}$ gas again and subjected to water bath sonication for at least $30 \mathrm{~min}$ at $55^{\circ} \mathrm{C}$. The lipid-paraffin mixture was allowed to cool at room temperature and $300 \mu \mathrm{L}$ of the mixture was transferred to a small glass tube. The inner solution mixture, composed of the PURE system, $200 \mathrm{mM}$ sucrose and the template DNA in a $30 \mu \mathrm{L}$ of reaction volume, was added at the bottom of the cooled lipid-paraffin mix. The emulsion was later formed by very brief and gentle pipette in-and-out. The prepared emulsion was then overlaid at the top of a $200 \mu \mathrm{L}$ ice-chilled outer solution consisting of the PURE buffer without tRNA and $200 \mathrm{mM}$ glucose in a 1:1 $(v / v)$ ratio. The mixture was further kept on ice for $10 \mathrm{~min}$ and centrifuged for $30 \mathrm{~min}$ at $10,000 \times g$ at $4{ }^{\circ} \mathrm{C}$. The precipitated GUV was collected by purging the Eppendorf tube at the bottom with $21 \mathrm{G}$ $\times 1 \frac{1}{2}$-inch needle. RNase was added to the collected supernatant at the concentration of $20 \mathrm{ng}_{\mu \mathrm{L}}^{-1}$ and the GUV suspension was incubated at $37^{\circ} \mathrm{C}$ for $6-8 \mathrm{~h}$. Finally, the localization of the sfGFP fused $\mathrm{CX}_{3} \mathrm{CR} 1$ was analyzed by confocal imaging. For sfGFP expression, the GUV was prepared from POPC and PEG2000-DOPE lipids.

\subsection{Determination of Binding Constants by the Surface Plasmon Resonance (SPR)}

SPR based ligand binding was carried out using Biacore T200 (GE Healthcare). Penta-His antibody (Qiagen) and strepMAB-Immo antibody (IBA Lifesciences) were immobilized on CM5 sensor chip using the standard amine coupling chemistry to capture His-tagged $\mathrm{CX}_{3} \mathrm{CR}$ 1-nanodisc complex and cell-free synthesized $\mathrm{CX}_{3} \mathrm{CL} 1$ containing Strep-tag II respectively. In brief, flow cell one, which was used as reference and flow cell two of the sensor chip were activated for 7 min with a 1:1 
mixture of 0.4 M EDC (1-ethyl-3-(3-dimethylaminopropyl)-carbodiimide) in water and 0.1 M NHS (N-hydroxysuccinimide) in water at a flow rate of $10 \mu \mathrm{L} / \mathrm{min}$. About $9000 \mathrm{RU}$ of Penta-His and 1000 RU of StrepMAB-Immo antibody at $50 \mu \mathrm{g} / \mathrm{mL}$ in $10 \mathrm{mM}$ sodium acetate, $\mathrm{pH} 5.0$ were immobilized for $7 \mathrm{~min}$ at a flow rate of $10 \mu \mathrm{L} / \mathrm{min}$ in a running buffer (HBS-P) containing $10 \mathrm{mM} \mathrm{HEPES,} \mathrm{pH} \mathrm{7.4,}$ $150 \mathrm{mM} \mathrm{NaCl}, 0.05 \%$ surfactant P20 for the nanodisc and micelle system respectively. To deactivate excessive reactive groups, the surfaces of both flow cells were blocked with a $1 \mathrm{M}$ ethanolamine, $\mathrm{pH}$ 8.5. After $6 \mathrm{~h}$ of incubation at $37^{\circ} \mathrm{C}$, cell-free synthesized His-tagged $\mathrm{CX}_{3} \mathrm{CR} 1 \mathrm{in}$ nanodisc $(\sim 300 \mathrm{kDa})$ and $\mathrm{CX}_{3}$ CL1-tagged with Strep-tag II $(8.5 \mathrm{kDa})$ were directly immobilized to flow cell two up to $\sim 1500 \mathrm{RU}$ and $1000 \mathrm{RU}$ respectively. For the nanodisc system, purified $\mathrm{CX}_{3} \mathrm{CL} 1$ diluted in the running buffer was injected on both flow cells at a concentration of $5 \mathrm{nM}, 10 \mathrm{nM}, 20 \mathrm{nM}, 40 \mathrm{nM}$ and $80 \mathrm{nM}$ and at a flow rate of $30 \mu \mathrm{L} / \mathrm{min}$ in the order of increasing concentration at $25^{\circ} \mathrm{C}$. The association and dissociation rate was set at 120 and $300 \mathrm{~s}$, respectively. For the micelle system, PURE expressed $C X_{3} C R 1$ in micelle was diluted in the running buffer and injected to both flow cells with the same condition as the nanodisc system. A $10 \mathrm{mM}$ glycine $/ \mathrm{HCl}, \mathrm{pH} 1.5$ was used for surface regeneration. The $\mathrm{K}_{\mathrm{D}}$ value was calculated with the Biacore T200 evaluation software version 3.0 using a 1:1 interaction model.

\subsection{Confocal Microscopy}

Confocal fluorescence microscopy was performed with an objective lens of $63 \times$. After PURE synthesis, $5 \mu \mathrm{L}$ of the sample was aliquoted and mixed with Nile red staining dye $(100 \mu \mathrm{M})$ and both green and blue channels were selected for taking images. Upon taking the images, the sensitivity of the laser was adjusted optimum by Zeiss software.

\section{Results}

\subsection{Membrane Protein Synthesis in Lipid Nanodisc}

To understand the functional and structural roles of a repertoire of GPCRs, we systematically examined their expression and productivity by the PURE system containing lipid nanodiscs. Due to the possibility of manipulating the PURE system reaction condition, we added nanodiscs to facilitate solubilization and stability of membrane protein interests. In this particular experiment, we supplemented the PURE system with lipid bilayers such as nanodiscs and evaluated the expression of the G-protein coupled receptors $\mathrm{CX}_{3} \mathrm{CR} 1$ and CCR5. In addition, since previous reports have shown that the insertion of rubredoxin, an iron-sulfur redox protein, into the third intracellular loop of CCR5 enhanced the thermostability $[25,32]$, we tested the expression of a fusion protein where rubredoxin was inserted to CCR5 (CCR5-Rb). Nanodiscs have been used to improve the stability and solubility of membrane proteins and widely used to study membrane proteins through reconstitution [30] and co-translational integration [33]. Consequently, the insertion and synthesis of membrane proteins are affected by the nanodiscs and incorporating the right size and concentration of nanodisc is essential. Thus, we investigated the effect of nanodiscs on the solubility of membrane proteins, which indicated the efficiency of membrane insertion, in the presence and absence of nanodiscs. A productivity of 0.05 $\mathrm{mg}, 0.04 \mathrm{mg}$ and $0.1 \mathrm{mg}$ per $\mathrm{mL}$ of PURE reaction was obtained for $\mathrm{CX}_{3} \mathrm{CR} 1$, CCR5 and CCR5-Rb, respectively which is sufficient to make a functional and structural analysis (Figure 2).

\subsection{Membrane Protein Synthesis in Micelle}

The secondary protein structures of PURE synthesized $\mathrm{CX}_{3} \mathrm{CR} 1$ and CCR5 were estimated by circular dichroism (CD) analysis. As the membrane scaffold protein in nanodisc is alpha helical and interferes with CD measurement of GPCRs, micelles and detergents are usually appropriate for $\mathrm{CD}$ analysis. Hence, we synthesized both $\mathrm{CX}_{3} \mathrm{CR} 1$ and CCR5 proteins by the PURE system containing a micelle and the purified proteins were used for $C D$ analysis. The $C D$ spectra showed a minima at around $208 \mathrm{~nm}$ and $222 \mathrm{~nm}$ indicating a typical characteristic feature of $\alpha$-helix proteins (Figure 3). The analysis of the $\alpha$-helix content of $\mathrm{CX}_{3} \mathrm{CR} 1$ and CCR5-Rb proteins in micelles by BeStSel 
software [34] showed a $40 \%$ and $49.5 \% \alpha$-helix content, respectively. The value for CCR5-Rb suggests the formation of a correct secondary structure with the expected 50\% $\alpha$-helix content for GPCRs. In the case of $C_{3} C R 1$, the value is slightly lower and the $C D$ analysis showed slightly higher beta content. We have currently no explanation for such lowered $\alpha$-helix and increased beta content for $\mathrm{CX}_{3} \mathrm{CR} 1$. Structural information might reveal these aspects in the future.

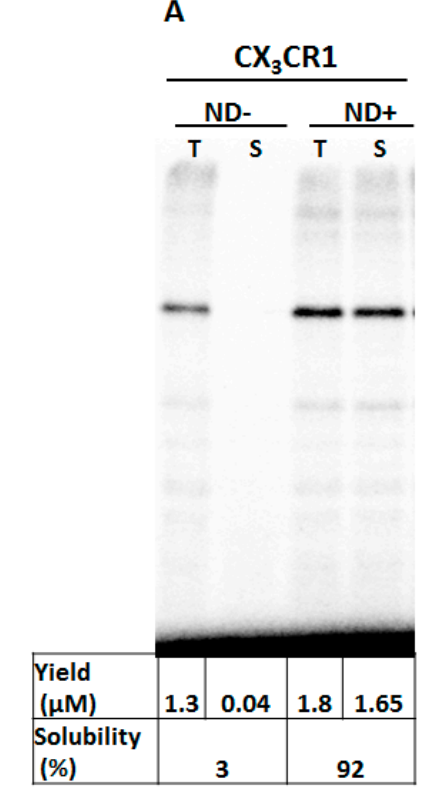

B

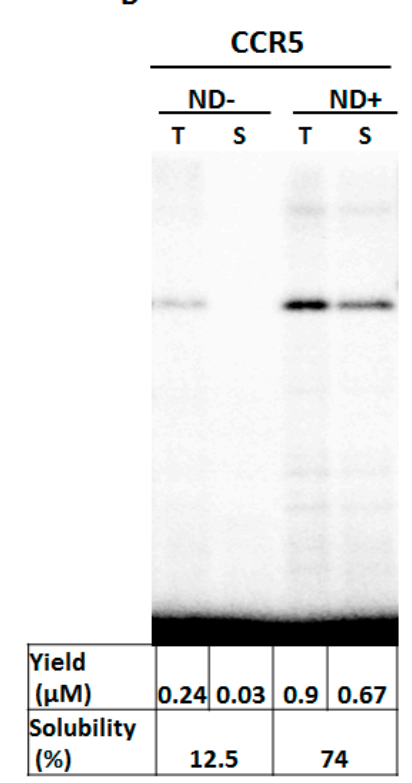

C

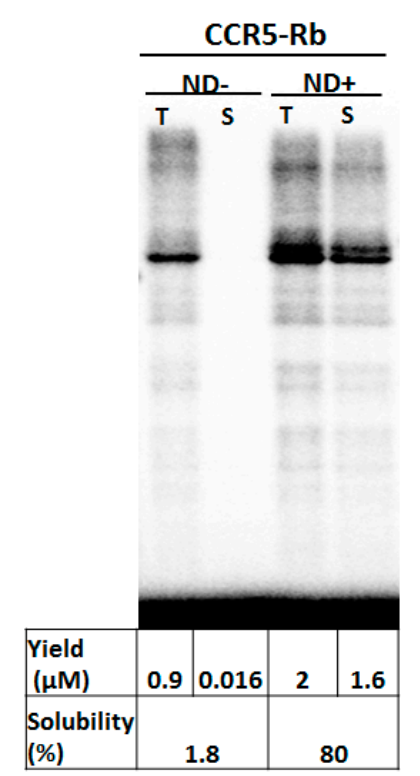

Figure 2. Productivity and solubility of cell-free expressed GPCRs. The GPCRs were expressed in

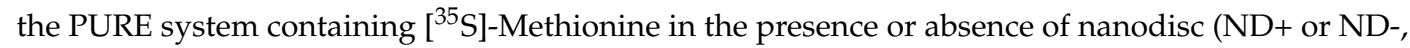
respectively). The productivity and solubility were subsequently quantified for $\mathrm{CX}_{3} \mathrm{CR} 1$ (A), CCR5 (B) and CCR5- $\mathrm{Rb}(\mathrm{C})$. The soluble fraction was quantified by dividing the supernatant (S) by the total (T) amount of synthesized protein.
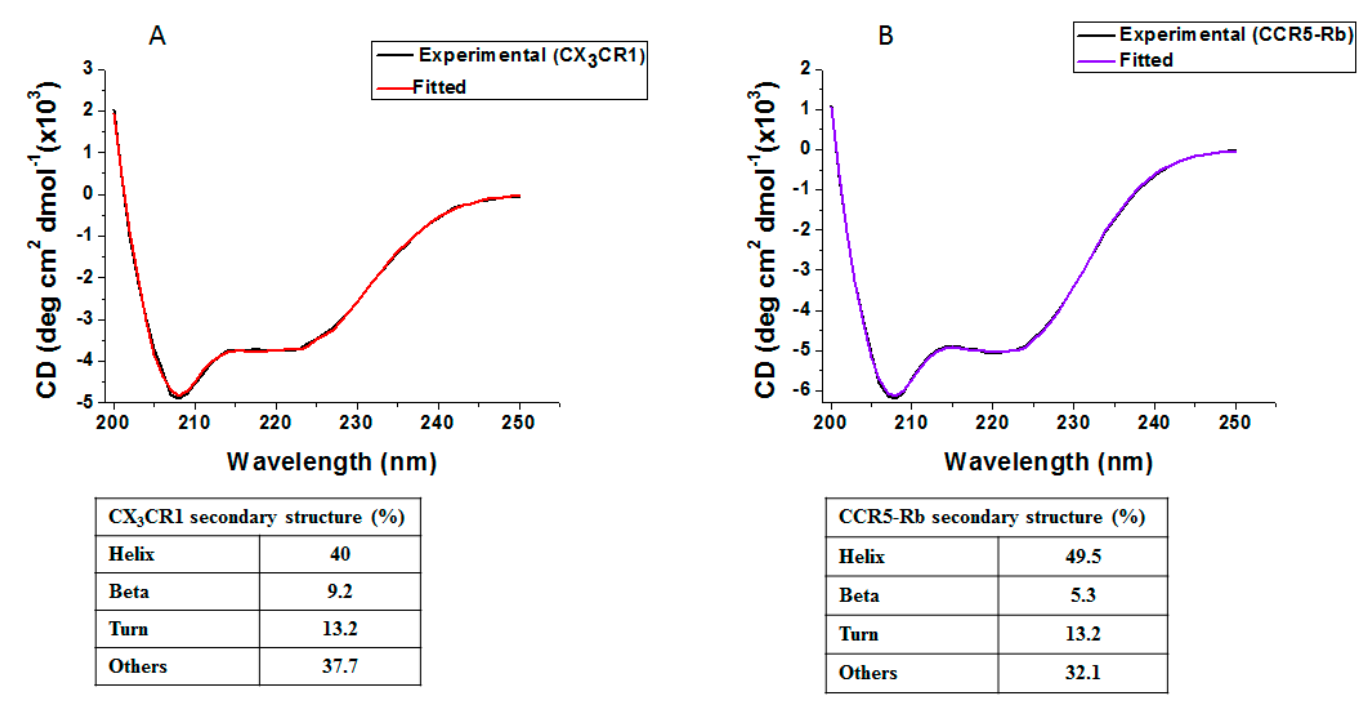

Figure 3. CD measurement of cell-free synthesized GPCRs. Secondary structures of PURE-synthesized $\mathrm{CX}_{3} \mathrm{CR} 1$ (A) and CCR5-Rb (B) in the presence of a micelle $(25 \mathrm{mg} / \mathrm{mL}$ brain polar lipid and $75 \mathrm{mg} / \mathrm{mL}$ digitonin) were analyzed. For CD measurement, the detergent was exchanged with a buffer containing $20 \mathrm{mM}$ Tris- $\mathrm{HCl} \mathrm{pH} 8.0,150 \mathrm{mM} \mathrm{NaCl}, 0.05 \%$ DDM and $0.002 \% \mathrm{CHS}$ during $\mathrm{Ni}^{2+}$ column chromatography. 


\subsection{Membrane Protein Synthesis in Nanodisc and Micelle}

The structure of CCR5 in complex with the antagonist ligand, maraviroc, has already been solved [25], whereas the structure of $\mathrm{CX}_{3} \mathrm{CR} 1$ has not yet been elucidated. Thus, we determined to further analyze the quality of synthesized $\mathrm{CX}_{3} \mathrm{CR} 1$ by measuring the affinity for its ligand fractalkine $\left(\mathrm{CX}_{3} \mathrm{CL1}\right)$ for the future structural analysis of cell-free synthesized GPCRs. For measurement of binding affinity, a nanodisc system and a micelle system were applied. We determined the binding affinity constant of $\mathrm{CX}_{3} \mathrm{CR} 1-\mathrm{CX}_{3} \mathrm{CL} 1$ interactions using SPR-based ligand binding assay and evaluated the interaction with the respective ligand by using the affinity values determined by radioligand binding assay as a reference. According to Hoover et al. [35], the fractalkine receptor, $\mathrm{CX}_{3} \mathrm{CR} 1$ binds the chemokine domain of the chemokine ligand with a $\mathrm{K}_{\mathrm{D}}$ value of $1-4 \mathrm{nM}$. For the SPR based assay, His-tagged $\mathrm{CX}_{3} \mathrm{CR} 1$ was synthesized by the PURE system in the presence of a nanodisc and the $\mathrm{CX}_{3} \mathrm{CR} 1$-nanodisc complex was immobilized directly on a sensor chip pre-immobilized with the anti-His antibody. A measured binding affinity of $27.8 \mathrm{nM}$ was obtained by injecting a recombinant $\mathrm{CX}_{3} \mathrm{CL1}$ protein to the sensor chip (Figure 4A). Inversely, to get a larger binding response and for stable and oriented binding, strep-II-tagged ligand $\mathrm{CX}_{3} \mathrm{CL1}$ was synthesized by the PURE system and immobilized on a sensor chip pre-immobilized with StrepMAB-Immo antibody. A measured binding affinity of $39.4 \mathrm{nM}$ was obtained when purified His-tagged $\mathrm{CX}_{3} \mathrm{CR} 1$ in detergent, which was synthesized by the PURE system containing micelles, was injected into the sensor chip (Figure 4B). This showed that functionally active membrane proteins can be synthesized using nanodiscs or micelles in a PURE system.
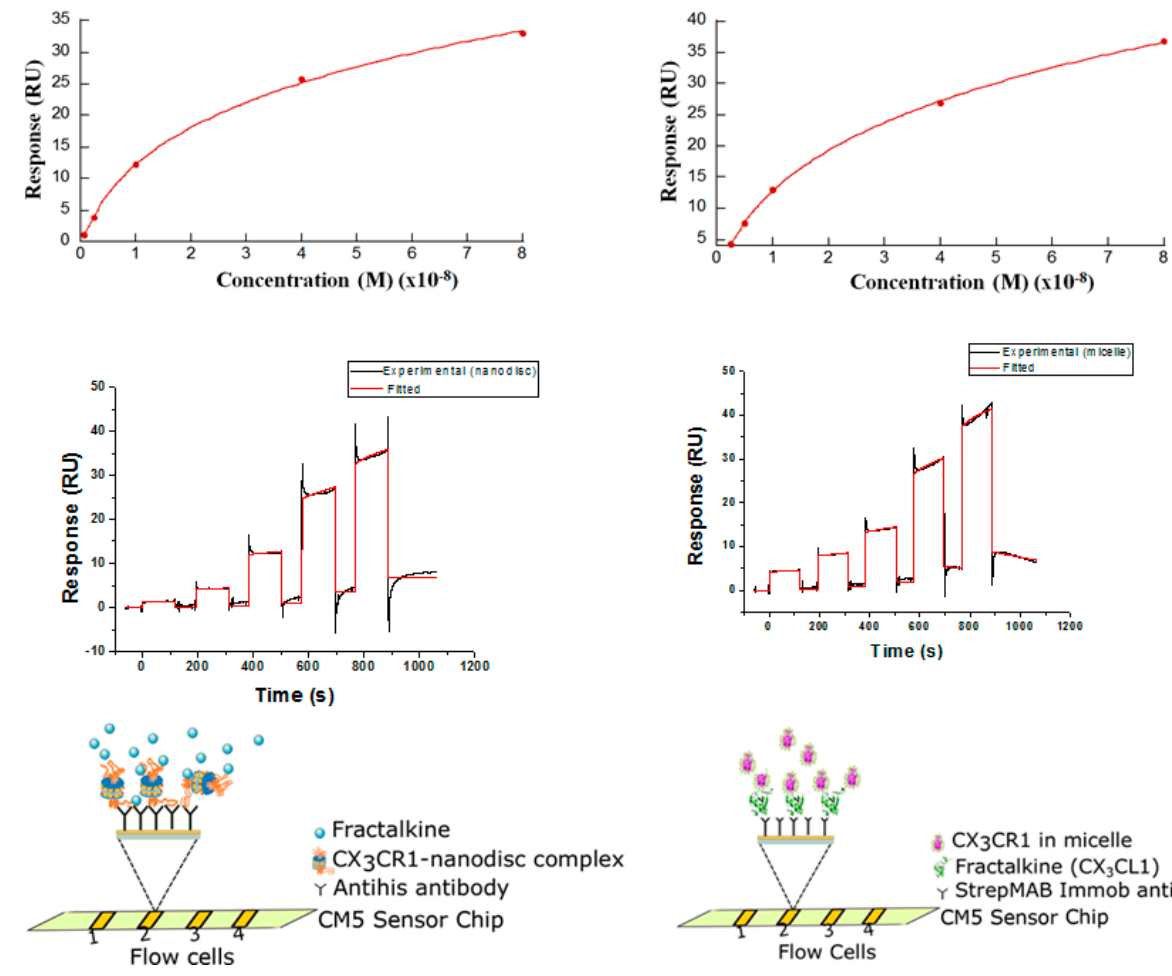

(A)

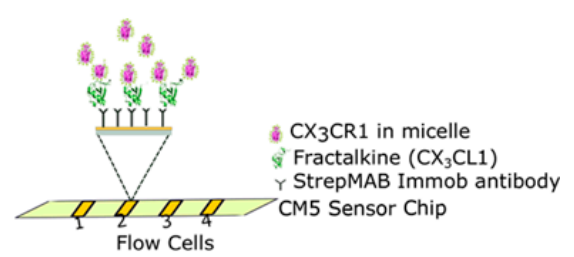

(B)

Figure 4. Receptor $\left(\mathrm{CX}_{3} \mathrm{CR} 1\right)$-ligand $\left(\mathrm{CX}_{3} \mathrm{CL1}\right)$ interaction in different environments. Schematic representation of receptor-ligand interaction in nanodisc $(\mathbf{A})$ and micelle $(\mathbf{B})$. In both $(\mathbf{A}, \mathbf{B})$, the upper, middle and lower figures correspond to the binding affinity constant, fitted kinetics and schematic representations of the immobilization strategy respectively. In all cases, the analytes at $2.5 \mathrm{nM}, 5 \mathrm{nM}$, $10 \mathrm{nM}, 40 \mathrm{nM}$ and $80 \mathrm{nM}$ concentrations were injected to determine the binding affinity constant using single cycle kinetics. For the nanodisc system, $\mathrm{CX}_{3} \mathrm{CL1}$ protein is denoted as the analyte and for the micelle system, His-tagged $\mathrm{CX}_{3} \mathrm{CR} 1$ is denoted as the analyte. 


\subsection{Membrane Protein Synthesis in GUV}

To investigate the membrane localization of cell-free synthesized $\mathrm{CX}_{3} \mathrm{CR} 1$, the protein fused with sfGFP at its C-terminus was synthesized in GUVs containing the PURE system inside and then, its localization was probed by confocal laser microscopy. The result showed that $\mathrm{CX}_{3} \mathrm{CR} 1$ was integrated and localized in the membrane than in the lumen of the GUV (Figure 5A). In contrast, when soluble sfGFP was synthesized in GUV by the PURE system, it was localized in the lumen of the GUV instead of being localized in the membrane (Figure 5B). According to the previous studies [13,15], synthesized $\mathrm{CX}_{3} \mathrm{CR} 1$ might be randomly inserted into GUV membrane, that is, the C-terminus of the protein facing inward and outward as shown in Figure 1C, which should be improved for efficient ligand or antibody binding studies using GUVs. However, these data indicated that appropriate localization of both membrane and soluble proteins can be achieved when they are synthesized in the presence of GUVs.
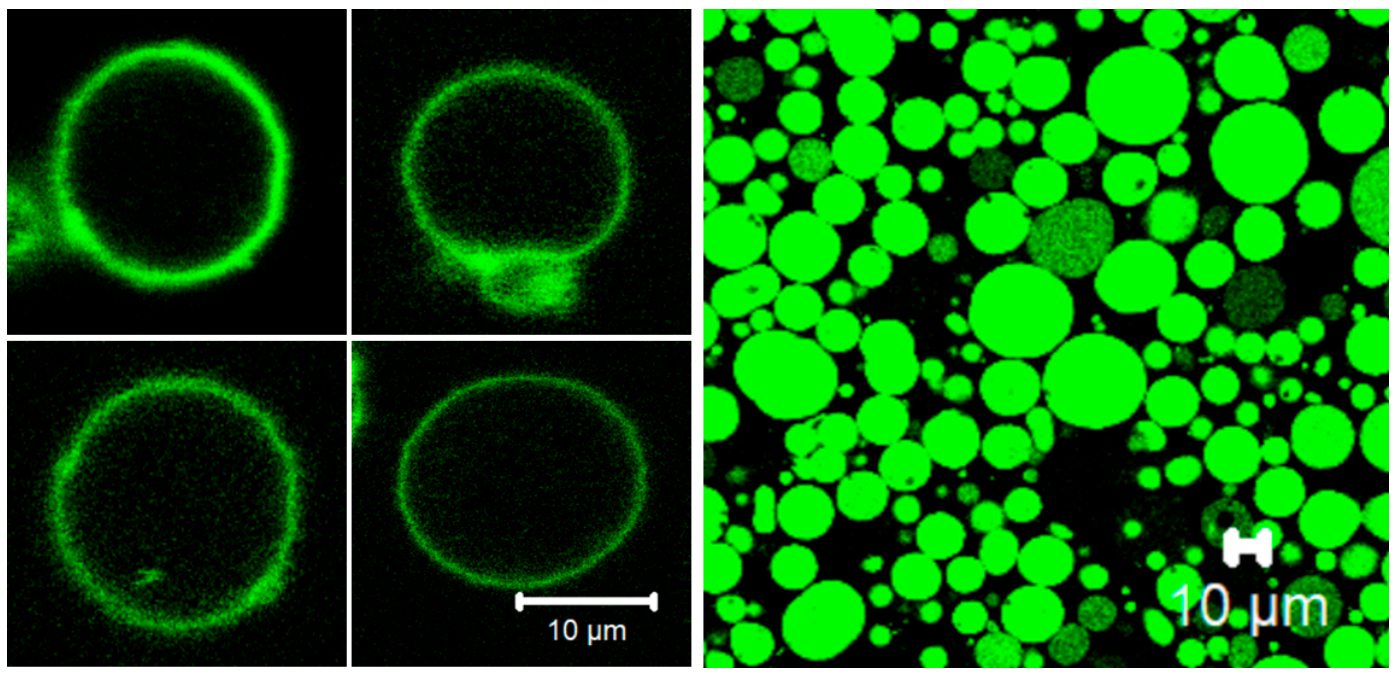

(A)

(B)

Figure 5. Membrane localization of cell-free synthesized receptor protein. (A) Spontaneous membrane integration of $\mathrm{CX}_{3} \mathrm{CR} 1$-sfGFP synthesized inside GUV. Four different representative GUV images taken under a different field of vision were presented. (B) sfGFP synthesized inside GUV as a control. Unlike $\mathrm{CX}_{3}$ CR1-sfGFP, sfGFP was localized in the lumen of the GUVs. The scale bars are $10 \mu \mathrm{m}$.

\subsection{Membrane Protein Synthesis in Nanodisc for Structural Analysis}

Nanodiscs have been used for the structural analysis of membrane proteins by cryo-electron microscopy (cryo-EM) [21,24]. To examine the possibility of cell-free synthesized $\mathrm{CX}_{3} \mathrm{CR} 1$ in nanodiscs, having a defined size that can be controlled by the scaffold protein, for further structural analyses and to confirm the stability and homogeneity of the complex, we carried out gel filtration chromatography and transmission electron microscopic analyses. The purified $\mathrm{CX}_{3} \mathrm{CR} 1$-nanodisc complex with $\mathrm{Ni}^{2+}$ affinity purification was further purified with size exclusion chromatography and the purity of the fractions containing the complex was confirmed on a 15\% SDS-PAGE. A discrete band of the scaffold protein (MSP1D1-) and $\mathrm{CX}_{3} \mathrm{CR} 1$ at $\sim 25 \mathrm{kDa}$ and $\sim 37 \mathrm{kDa}$, respectively, were detected (Figure 6A,B). The purified $\mathrm{CX}_{3} \mathrm{CR} 1$-nanodisc complex was further analyzed by transmission electron microscopy and a homogeneous $\mathrm{CX}_{3} \mathrm{CR} 1$-nanodisc complex with a defined size was obtained without an aberrant change in nanodisc size as a result of protein insertion (Figure 6C). In addition, even though it requires further analysis, the SDS-PAGE suggests the insertion of a monomer $C_{2} C R 1$ per nanodisc. Thus, the complex can be used to examine the 3D structure of membrane proteins in their native-like environment. 

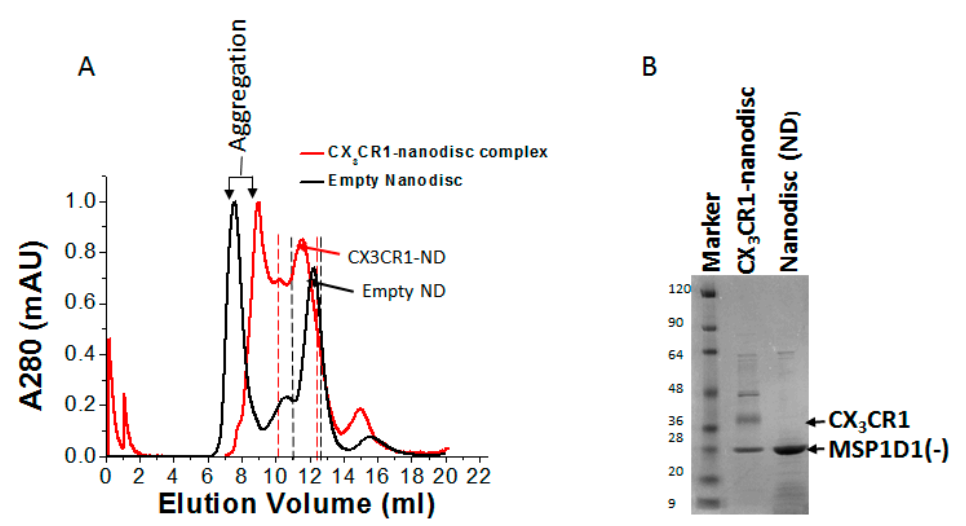

C

Figure 6. Analysis of $\mathrm{CX}_{3} \mathrm{CR}$ 1-nanodisc complex by gel filtration and negative staining. (A) Elution pattern of the $\mathrm{CX}_{3} \mathrm{CR}$ 1-nanodisc complex (red) and empty nanodisc (black) as observed during the size exclusion chromatography. The peak was normalized to the elution profile of empty nanodisc. (B) SDS-PAGE analysis of the elution fraction stained by Coomassie Brilliant Blue (CBB). (C) Homogeneity of $\mathrm{CX}_{3} \mathrm{CR} 1$-nanodisc complex analyzed by transmission electron. The scale bar is $50 \mathrm{~nm}$.

\section{Discussion}

Cell-free translation systems are used to produce target proteins within a few hours and they are expected to supersede the cell-based expression for functional analysis of membrane proteins due to the advantage in expression and purification processes. In synthetic biology, cell-free systems are indispensable to construct artificial cells capable of mimicking the cellular environment for the investigation of difficult-to-express membrane proteins such as the G-protein coupled receptors [36,37]. In this study, we employed the PURE system to synthesize chemokine G-protein coupled receptors co-translationally in the presence of nanodiscs, micelles and GUVs to enhance their conformational stability and activity.

Producing GPCRs in a cell-free system is inherently challenging due to their aggregation properties and demands in the optimization of the system to obtain active proteins. It was demonstrated by Chi et al. [13] that supplementing the cell-free system with chaperones yields a functional CCR5 with the expected binding affinity. Chemokine receptors and their ligands play a crucial role in the immune system and implicated in various pathophysiological disease [38,39]. However, functional studies of GPCRs in vitro was mainly hampered by precipitation. Thus, translation of $\mathrm{CX}_{3} \mathrm{CR} 1$ and CCR5 chemokine GPCRs in a cell-free system without modification of the system through the addition of lipid bilayers and micelles leads to aggregation and low productivity (Figure 2). The stability and productivity of GPCRs can further be improved by the insertion of a thermostabilizing fragment such as an iron-sulfur redox protein, rubredoxin, at the third intracellular loop of target GPCRs [32]. In our system, insertion of rubredoxin $(\mathrm{Rb})$ to CCR5 improved the productivity in the presence of nanodisc (ND+) by twofold and by fourfold in the absence of nanodisc (ND-) as compared to the yield of CCR5. Whereas the solubility showed no significant improvement despite rubredoxin insertion.

The heptahelical transmembrane of GPCRs is characterized by their $\alpha$-helix content. Wiktor et al. [40,41] investigated the secondary structure of CCR5 expressed in E. coli and confirmed the presence of a minima at around $208 \mathrm{~nm}$ and $222 \mathrm{~nm}$ which is a typical characteristic of $\alpha$-helix proteins. As the scaffold protein in nanodiscs contains $\alpha$-helical structure which interferes with CD measurements, $C X_{3} C R 1$ and CCR5 chemokine receptors were expressed by the PURE system supplemented with detergents and micelles. Micelles composed of a brain polar lipid and digitonin detergent were appropriate as most chemokine receptors are expressed in the brain $[42,43]$. Hence, the brain polar lipid containing a mixture of lipids is expected to provide enhanced stability and activity of $\mathrm{CX}_{3} \mathrm{CR} 1$ and $\mathrm{CCR} 5$ chemokine receptors. Therefore, we examined the secondary structure of $\mathrm{CX}_{3} \mathrm{CR} 1$ and $\mathrm{CCR} 5-\mathrm{Rb}$ synthesized by the PURE system in the presence of a micelle and obtained a 
typical characteristic of folded $\alpha$-helix identical to the in vivo expressed GPCRs [41]. Though structural analysis of cell-free synthesized $\mathrm{CX}_{3} \mathrm{CR} 1$ is necessary to confirm proper folding, the secondary structure indicates the presence of proper folded $\mathrm{CX}_{3} \mathrm{CR} 1$ and CCR5-Rb synthesized by the PURE system (Figure 3) $[40,41]$. Nonetheless, the fraction of properly folded receptors in the PURE system is unknown and not yet determined from the secondary structure measurement. Furthermore, NMR analysis of cell-free expressed chemokine GPCRs through $13 \mathrm{CH} 3$ methionine will be a substantial approach to better understand the conformational changes of the receptor and will strengthen the secondary structural analysis as it was reported for other classes of GPCRs [36].

The interaction of chemokine receptors with their respective ligands determine the functionality of synthesized receptors. Surface plasmon resonance is a label-free assay method used to study ligand-receptor protein interactions and capable of measuring the interactions with high sensitivity and robustness [44]. Shepherd et al. [45] and Rues et al. [22] applied SPR to determine the binding affinity constant of CCR5 in detergent and $\beta 1 \mathrm{AR}$ reconstituted into nanodiscs. In addition, Shinoda et al. [14] determined the binding affinity constant for cell-free synthesized claudin- 4 in a micelle by SPR. Taking advantage of the manipulation of the PURE system reaction condition, we synthesized $\mathrm{CX}_{3} \mathrm{CR} 1$ in the presence of nanodiscs and micelles and measured ligand-receptor interactions.

$\mathrm{CX}_{3} \mathrm{CR} 1$ synthesized by the PURE system was directly immobilized on a sensor chip pre-immobilized with anti-His antibody and a binding affinity comparative to the affinity determined by radioligand binding of in vivo expressed $\mathrm{CX}_{3} \mathrm{CR} 1$ protein was achieved [46]. Nanodiscs enhanced the stability of membrane proteins by lowering the dissociation rate constant and minimizing the disparity in binding affinity constants compared to other methods [47]. Similarly, we succeeded in the synthesis of a chemokine ligand, $\mathrm{CX}_{3} \mathrm{CL1}$, by the PURE system and immobilized directly on a sensor chip pre-immobilized with StrepMAB-Immo antibody. $\mathrm{CX}_{3} \mathrm{CR} 1$ synthesized by the PURE system containing a micelle, interacted with immobilized ligand and a binding affinity was determined. The binding affinity constants for both systems are outside the range of previously reported values of 1-4 $\mathrm{nM}$ by radioligand binding [35]. The possible reason for the discrepancy in binding affinity constant can be explained by the fact that different assay systems or experimental conditions result in a different calculated affinity constant.

Membrane protein analysis can be achieved by using a cell-free system in the presence of nanodiscs, micelles and GUVs. Therefore, our system has a great potential for investigating the functions of membrane proteins including orphan GPCRs. Furthermore, our system can easily be adapted to study oligomerization of GPCRs and other membrane proteins. Most importantly, the synergy of the cell-free system and the nanodisc technology has a tremendous advantage for investigating the structures of membrane proteins in a native-like environment by cryo-electron microscopy (cryo-EM).

Author Contributions: Conceptualization, T.U.; Formal Analysis, T.N., K.N. and Y.S.; Funding acquisition, Y.S. and T.U.; Investigation, B.G.; Methodology, T.U.; Supervision, T.U.; Validation, K.N. and Y.S.; Writing-original draft, B.G.; Writing-review \& editing, T.N., K.N. and Y.S.

Funding: This work was supported by the Platform for Drug Discovery, Informatics and Structural Life Science, Japan Agency for Medical Research and Development (T.U.) and supported in part by Grant-in-Aid with numbers of 17 H05680 (Y.S.) from the Japan Society for the Promotion of Science (JSPS), an intramural Grant-in-Aid from the RIKEN Center for Biosystems Dynamics Research (Y.S.). A part of this work was supported by Nanotechnology Platform Project "(Nanotechnology Open Facilities in Osaka University)" of Ministry of Education, Culture, Sports, Science and Technology, Japan [No.: A-17-OS-0063].

Acknowledgments: We thank Yutaka Suzuki (The University of Tokyo) for providing us the cDNA, Yuji Goto and Masatomo So (Institute for Protein Research, Osaka University) for letting us to use the CD spectroscopy and fruitful discussion, Kaoru Mitsuoka (Research Center for Ultra-High Voltage Electron Microscopy, Osaka University) and Eri Hirata (The University of Tokyo) for the negative staining images, Samuel Berhanu for processing confocal images, Masaru Tanokura, Takuya Miyakawa (The University of Tokyo) and Junichi Takagi (Osaka University) for allowing us to use the SPR facility and Takashi Kanamori (Genefrontier), Eriko Osada and Tomoe Murakami (The University of Tokyo) for preparing the PURE system. We also thank Kylius Wilkins (BDR, RIKEN) for the English corrections in this manuscript.

Conflicts of Interest: The authors declare no conflict of interest. 


\section{References}

1. Shen, H.H.; Lithgow, T.; Martin, L. Reconstitution of Membrane Proteins into Model Membranes: Seeking Better Ways to Retain Protein Activities. Int. J. Mol. Sci. 2013, 14, 1589-1607. [CrossRef] [PubMed]

2. Sachse, R.; Dondapati, S.K.; Fenz, S.F.; Schmidt, T.; Kubick, S. Membrane protein synthesis in cell-free systems: From bio-mimetic systems to bio-membranes. FEBS Lett. 2014, 588, 2774-2781. [CrossRef] [PubMed]

3. Overington, J.P.; Al-Lazikani, B.; Hopkins, A.L. How many drug targets are there? Nat. Rev. Drug Discov. 2006, 5, 993-996. [CrossRef] [PubMed]

4. Venkatakrishnan, A.J.; Deupi, X.; Lebon, G.; Tate, C.G.; Schertler, G.F.; Babu, M.M. Molecular signatures of G-protein-coupled receptors. Nature 2013, 494, 185-194. [CrossRef] [PubMed]

5. Stevens, R.C.; Cherezov, V.; Katritch, V.; Abagyan, R.; Kuhn, P.; Rosen, H.; Wüthrich, K. The GPCR Network: A large-scale collaboration to determine human GPCR structure and function. Nat. Rev. Drug Discov. 2013, 12, 25-34. [CrossRef] [PubMed]

6. Lappano, R.; Maggiolini, M. G protein-coupled receptors: Novel targets for drug discovery in cancer. Nat. Rev. Drug Discov. 2011, 10, 47-60. [CrossRef] [PubMed]

7. Noireaux, V.; Libchaber, A. A vesicle bioreactor as a step toward an artificial cell assembly. Proc. Natl. Acad. Sci. USA 2004, 101, 17669-17674. [CrossRef] [PubMed]

8. Fujii, S.; Matsuura, T.; Sunami, T.; Nishikawa, T.; Kazuta, Y.; Yomo, T. Liposome display for in vitro selection and evolution of membrane proteins. Nat. Protoc. 2014, 9, 1578-1591. [CrossRef] [PubMed]

9. Yanagisawa, M.; Iwamoto, M.; Kato, A.; Yoshikawa, K.; Oiki, S. Oriented reconstitution of a membrane protein in a giant unilamellar vesicle: Experimental verification with the potassium channel KcsA. J. Am. Chem. Soc. 2011, 133, 11774-11779. [CrossRef] [PubMed]

10. Hamada, S.; Tabuchi, M.; Toyota, T.; Sakurai, T.; Hosoi, T.; Nomoto, T.; Nakatani, K.; Fujinami, M.; Kanzaki, R. Giant vesicles functionally expressing membrane receptors for an insect pheromone. Chem. Commun. (Camb.) 2014, 50, 2958-2961. [CrossRef] [PubMed]

11. Misawa, N.; Osaki, T.; Takeuchi, S. Membrane protein-based biosensors. J. R. Soc. Interface $2018,15$. [CrossRef] [PubMed]

12. Shimizu, Y.; Inoue, A.; Tomari, Y.; Suzuki, T.; Yokogawa, T.; Nishikawa, K.; Ueda, T. Cell-free translation reconstituted with purified components. Nat. Biotechnol. 2001, 19, 751-755. [CrossRef] [PubMed]

13. Chi, H.; Wang, X.; Li, J.; Ren, H.; Huang, F. Folding of newly translated membrane protein CCR5 is assisted by the chaperonin GroEL-GroES. Sci. Rep. 2015, 5, 17037. [CrossRef] [PubMed]

14. Shinoda, T.; Shinya, N.; Ito, K.; Ishizuka-Katsura, Y.; Ohsawa, N.; Terada, T.; Hirata, K.; Kawano, Y.; Yamamoto, M.; Tomita, T.; et al. Cell-free methods to produce structurally intact mammalian membrane proteins. Sci. Rep. 2016, 6, 30442. [CrossRef] [PubMed]

15. Matsubayashi, H.; Kuruma, Y.; Ueda, T. In vitro synthesis of the, E. coli Sec translocon from DNA. Angew. Chem. Int. Ed. Engl. 2014, 53, 7535-7538. [CrossRef] [PubMed]

16. Rues, R.B.; Dong, F.; Dötsch, V.; Bernhard, F. Systematic optimization of cell-free synthesized human endothelin B receptor folding. Methods 2018, 147, 73-83. [CrossRef] [PubMed]

17. Denisov, I.G.; Sligar, S.G. Nanodiscs in Membrane Biochemistry and Biophysics. Chem. Rev. 2017, 117, 4669-4713. [CrossRef] [PubMed]

18. Inagaki, S.; Ghirlando, R.; Grisshammer, R. Biophysical characterization of membrane proteins in nanodiscs. Methods 2013, 59, 287-300. [CrossRef] [PubMed]

19. Yoshiura, C.; Kofuku, Y.; Ueda, T.; Mase, Y.; Yokogawa, M.; Osawa, M.; Terashima, Y.; Matsushima, K.; Shimada, I. NMR analyses of the interaction between CCR5 and its ligand using functional reconstitution of CCR5 in lipid bilayers. J. Am. Chem. Soc. 2010, 32, 6768-6777. [CrossRef] [PubMed]

20. Gao, Y.; Cao, E.; Julius, D.; Cheng, Y. TRPV1 structures in nanodiscs reveal mechanisms of ligand and lipid action. Nature 2016, 534, 347-351. [CrossRef] [PubMed]

21. Mi, W.; Li, Y.; Yoon, S.H.; Ernst, R.K.; Walz, T.; Liao, M. Structural basis of MsbA-mediated lipopolysaccharide transport. Nature 2017, 549, 233-237. [CrossRef] [PubMed]

22. Rues, R.B.; Dötsch, V.; Bernhard, F. Co-translational formation and pharmacological characterization of beta1-adrenergic receptor/nanodisc complexes with different lipid environments. Biochim. Biophys. Acta 2016, 1858, 1306-1316. [CrossRef] [PubMed] 
23. Klammt, C.; Srivastava, A.; Eifler, N.; Junge, F.; Beyermann, M.; Schwarz, D.; Michel, H.; Doetsch, V.; Bernhard, F. Functional analysis of cell-free-produced human endothelin B receptor reveals transmembrane segment 1 as an essential area for ET-1 binding and homodimer formation. FEBS J. 2007, 274, 3257-3269. [CrossRef] [PubMed]

24. Efremov, R.G.; Gatsogiannis, C.; Raunser, S. Lipid Nanodiscs as a Tool for High-Resolution Structure Determination of Membrane Proteins by Single-Particle Cryo-EM. Methods Enzymol. 2017, 594, 1-30. [CrossRef] [PubMed]

25. Tan, Q.; Zhu, Y.; Li, J.; Chen, Z.; Han, G.W.; Kufareva, I.; Li, T.; Ma, L.; Fenalti, G.; Li, J.; et al. Structure of the CCR5 chemokine receptor-HIV entry inhibitor maraviroc complex. Science 2013, 341, 1387-1390. [CrossRef] [PubMed]

26. Shimizu, Y.; Kuruma, Y.; Kanamori, T.; Ueda, T. The PURE system for protein production. Methods Mol. Biol. 2014, 1118, 275-284. [CrossRef] [PubMed]

27. Ritchie, T.K.; Grinkova, Y.V.; Bayburt, T.H.; Denisov, I.G.; Zolnerciks, J.K.; Atkins, W.M.; Sligar, S.G. Reconstitution of membrane proteins in phospholipid bilayer nanodiscs. Methods Enzymol. 2009, 464, 211-231. [CrossRef] [PubMed]

28. Bayburt, T.H.; Sligar, S.G. Membrane protein assembly into Nanodiscs. FEBS Lett. 2010, 584, $1721-1727$. [CrossRef] [PubMed]

29. Denisov, I.G.; Grinkova, Y.V.; Lazarides, A.A.; Sligar, S.G. Directed self-assembly of monodisperse phospholipid bilayer Nanodiscs with controlled size. J. Am. Chem. Soc. 2004, 126, 3477-3487. [CrossRef] [PubMed]

30. Lamichhane, R.; Liu, J.J.; Pauszek, R.F.; Millar, D.P. Fluorophore Labeling, Nanodisc Reconstitution and Single-molecule Observation of a G Protein-coupled Receptor. Bio-Protocol 2017, 7. [CrossRef] [PubMed]

31. Shimizu, Y.; Ueda, T. PURE technology. Methods Mol. Biol. 2010, 607, 11-21. [CrossRef] [PubMed]

32. Chun, E.; Thompson, A.A.; Liu, W.; Roth, C.B.; Griffith, M.T.; Katritch, V.; Kunken, J.; Xu, F.; Cherezov, V.; Hanson, M.A.; et al. Fusion partner toolchest for the stabilization and crystallization of $\mathrm{G}$ protein-coupled receptors. Structure 2012, 20, 967-976. [CrossRef] [PubMed]

33. Henrich, E.; Dötsch, V.; Bernhard, F. Screening for lipid requirements of membrane proteins by combining cell-free expression with nanodiscs. Methods Enzymol. 2015, 556, 351-369. [CrossRef] [PubMed]

34. Micsonai, A.; Wien, F.; Kernya, L.; Lee, Y.H.; Goto, Y.; Réfrégiers, M.; Kardos, J. Accurate secondary structure prediction and fold recognition for circular dichroism spectroscopy. Proc. Natl. Acad. Sci. USA 2015, 112, E3095-E3103. [CrossRef] [PubMed]

35. Hoover, D.M.; Mizoue, L.S.; Handel, T.M.; Lubkowski, J. The Crystal Structure of the Chemokine Domain of Fractalkine Shows a Novel Quaternary Arrangement. J. Biol. Chem. 2000, 275, 23187-23193. [CrossRef] [PubMed]

36. Shilling, P.J.; Bumbak, F.; Scott, D.J.; Bathgate, R.A.D.; Gooley, P.R. Characterisation of a cell-free synthesised G-protein coupled receptor. Sci. Rep. 2017, 7, 1094. [CrossRef] [PubMed]

37. Cook, B.L.; Steuerwald, D.; Kaiser, L.; Graveland-Bikker, J.; Vanberghem, M.; Berke, A.P.; Herlihy, K.; Pick, H.; Vogel, H.; Zhang, S. Large-scale production and study of a synthetic G protein-coupled receptor: Human olfactory receptor 17-4. Proc. Natl. Acad. Sci. USA 2009, 106, 11925-11930. [CrossRef] [PubMed]

38. Ren, H.; Yu, D.; Ge, B.; Cook, B.; Xu, Z.; Zhang, S. High-level production, solubilization and purification of synthetic human GPCR chemokine receptors CCR5, CCR3, CXCR4 and CX3CR1. PLoS ONE 2009, 4, e4509. [CrossRef] [PubMed]

39. Miller, M.C.; Mayo, K.H. Chemokines from a Structural Perspective. Int. J. Mol. Sci. 2017, 18, 2088. [CrossRef] [PubMed]

40. Wiktor, M.; Morin, S.; Sass, H.J.; Kebbel, F.; Grzesiek, S. Biophysical and structural investigation of bacterially expressed and engineered CCR5, a G protein-coupled receptor. J. Biomol. NMR 2013, 55, 79-95. [CrossRef] [PubMed]

41. Corin, K.; Baaske, P.; Ravel, D.B.; Song, J.; Brown, E.; Wang, X.; Geissler, S.; Wienken, C.J.; Jerabek-Willemsen, M.; Duhr, S.; et al. A robust and rapid method of producing soluble, stable, and functional G-protein coupled receptors. PLoS ONE 2011, 6, e23036. [CrossRef] [PubMed]

42. Sorce, S.; Myburgh, R.; Krause, K.H. The chemokine receptor CCR5 in the central nervous system. Prog. Neurobiol. 2011, 93, 297-311. [CrossRef] [PubMed] 
43. Hulshof, S.; van Haastert, E.S.; Kuipers, H.F.; van den Elsen, P.J.; De Groot, C.J.; van der Valk, P.; Ravid, R.; Biber, K. CX3CL1 and CX3CR1 expression in human brain tissue: Noninflammatory control versus multiple sclerosis. J. Neuropathol. Exp. Neurol. 2003, 62, 899-907. [CrossRef] [PubMed]

44. Chu, R.; Reczek, D.; Brondyk, W. Capture-stabilize approach for membrane protein SPR assays. Sci. Rep. 2014, 4, 7360. [CrossRef] [PubMed]

45. Shepherd, C.A.; Hopkins, A.L.; Navratilova, I. Fragment screening by SPR and advanced application to GPCRs. Prog. Biophys. Mol. Biol. 2014, 116, 113-123. [CrossRef] [PubMed]

46. Harrison, J.K.; Fong, A.M.; Swain, P.A.; Chen, S.; Yu, Y.R.; Salafranca, M.N.; Greenleaf, W.B.; Imai, T.; Patel, D.D. Mutational analysis of the fractalkine chemokine domain. Basic amino acid residues differentially contribute to CX3CR1 binding, signaling, and cell adhesion. J. Biol. Chem. 2001, 276, 21632-21641. [CrossRef] [PubMed]

47. Guo, D.; Heitman, L.H.; IJzerman, A.P. Kinetic Aspects of the Interaction between Ligand and G Protein-Coupled Receptor: The Case of the Adenosine Receptors. Chem. Rev. 2017, 117, 38-66. [CrossRef] [PubMed]

(C) 2018 by the authors. Licensee MDPI, Basel, Switzerland. This article is an open access article distributed under the terms and conditions of the Creative Commons Attribution (CC BY) license (http:/ / creativecommons.org/licenses/by/4.0/). 